\title{
Effects of Duty Cycle and Pulse Frequency on the Microstructure and Mechanical Properties of TiAlN Coatings
}

\author{
Sung-Yong Chun ${ }^{\dagger}$ and Ju Yeon Hwang \\ Department of Advanced Materials Science and Engineering, Mokpo National University, Jeonnam 534-729, Korea \\ (Received August 13, 2014; Revised September 16, 2014; Accepted September 17, 2014)

\section{듀티 싸이클 및 펄스 주파수가 TiAIN 코팅막의 미세구조와 기계적 특성에 미치는 영향에 관한 연구}

\author{
전성용 ${ }^{\dagger}$. 황주연 \\ 목포대학교 신소재공학과
}

(2014년 8월 13일 접수 ; 2014년 9월 16일 수정 ; 2014년 9월 17일 채택)

\begin{abstract}
This paper presents the effects of pulse plasma parameters such as duty cycle and pulse frequency on the properties of TiAlN coatings deposited by asymmetric bipolar pulsed DC magnetron sputtering systems. The results show that, with decreasing duty cycle and increasing pulse frequency, the coating morphology changes from a columnar structure to a dense structure with finer grains. Pulsed sputtered TiAIN coatings showed higher hardness, higher residual stress, and smaller grain sizes than did DC prepared TiAIN coatings. Moreover, residual stress and nanoindentation hardness of pulsed sputtered TiAlN coatings increased with increasing pulse frequency. Meanwhile, the surface roughness decreased continuously with increasing pulsed DC frequency up to $50 \mathrm{kHz}$.
\end{abstract}

Key words : Asymmetric bipolar, Duty cycle, Pulse frequency, Nanoindentation, Surface morphology

\section{1. 서 론}

TiAlN은 내마모성과 고경도와 같은 기계적 성질이 요 구되는 절삭공구, 기계부품의 수명을 향상시키기 위한 코 팅막으로 널리 이용되고 있다. ${ }^{1,2)}$ 최근에는 전통적인 기 계부품 응용분야 외에 의학 진단용 바이오센서, 고분자 표면처리, 전지의 촉매 지지 등으로 응용이 다양화되고 있다. ${ }^{3-5)}$ 이러한 TiAlN 코팅막을 제작하는 대표적인 방법 으로 이온 플레이팅, 이온 빔 스퍼터법과 반응성 마그네 트론 스퍼터법 등을 들 수 있다. $\left.{ }^{6}\right) \mathrm{PVD}$ 법 중에서도 마그 네트론 스퍼터법은 뛰어난 재현성과 밀착력 뿐만 아니라 높은 증착율과 낮은 기판온도에서도 코팅이 가능하기 때 문에 가장 널리 사용되고 있다. 그러나 미세구조가 불 균 일한 주상구조를 나타내거나 다공성의 코팅막이 생성되 기 쉽기 때문에 물성 면에서는 불리하다. ${ }^{7)}$ 따라서 본 연 구에서는 펄스 플라즈마의 중요 변수인 타겟에 인가되는 듀티 싸이클과 펄스 주파수 인가방법을 조절함으로써 코

${ }^{\dagger}$ Corresponding author : Sung-Yong Chun

E-mail : sychun@mokpo.ac.kr

Tel : +82-61-450-2495 Fax : +82-61-450-2498
팅막의 특성을 조절할 수 있는 비대칭 바이폴라 펄스 $\mathrm{DC}$ 스퍼터법에 주목하였다. 특히 바이폴라 펄스 $\mathrm{DC}$ 마그네 트론 스퍼터법은 기존의 $\mathrm{DC}$ 스퍼터법에 비해 펄스 전원 을 사용하기 때문에 $(+)$ 전압이 인가되는 시간의 존재로 인하여 아크발생이 근본적으로 억제된다. 따라서 미세 아 크로 인해 발생하는 시편의 결함을 방지할 수 있고 플라 즈마에 안정성이 높아진다. 또한 펄스 $\mathrm{DC}$ 스퍼터법은 $\mathrm{DC}$ 스퍼터법에 비해 높은 이온 플럭스와 넓은 이온 에너지 분포를 갖는다고 보고되고 있기 때문에 높은 이온 에너 지를 갖는 이온 플럭스의 증가는 코팅막의 조성, 조직계 수, 미세구조와 물성 등에 커다란 영향을 미칠 것으로 사 료된다. ${ }^{8)}$ 현재까지 주로 $\mathrm{TiN}$ 보다 우수한 내산화성과 높 은 경도를 얻기 위해 다양한 PVD법을 이용한 TiAIN 코 팅막 제작에 관한 연구는 많이 발표되었으나 듀티 싸이 클과 펄스 주파수와 같은 펄스 플라즈마 공정변수가 TiAlN 코팅막의 평균 결정립 크기와 표면 및 단면 미세구조의 치밀화에 미치는 영향을 정량적으로 분석 및 고찰한 연 구결과는 거의 보고된 바 없다.,10)

따라서 본 연구에서는 펄스 플라즈마 전원의 사용, 듀 티 싸이클과 펄스 주파수와 같은 펄스 플라즈마 공정 변 수가 TiAlN 코팅막의 물성에 미치는 영향을 조사하기 위 
해 종래의 연속적인 $\mathrm{DC}$ 스퍼터와 비대칭 바이폴라 펄스 $\mathrm{DC}$ 스퍼터를 이용하여 TiAIN 코팅막을 각각 제작하였다. 이때 펄스 플라즈마 변수가 TiAlN 코팅막의 나노결정립 크기, 2 차원 표면 및 단면관찰과 3 차원 몰폴러지와 표면 거칠기와 같은 미세구조적 변화에 미치는 영향에 주목하 여 고찰하였다. 또한 우선 배향성, 잔류응력, 나노인덴테 이션 경도와 같은 기계물리학적 특성에 미치는 영향도 고 찰하였다.

\section{2. 실험 방법}

본 실험에서는 $\mathrm{Si}(100)$ 기판을 사용하였고, 기판표면의 불순물을 제거하기 위하여 초음파 세척기를 이용하여 아 세톤과 에틸 알코올에서 각각 10 분간 세척을 실시한 후 건조하였다. 본 실험에서 사용한 코팅장비는 비대칭 펄스 $\mathrm{DC}$ 반응성 마그네트론 스퍼터 장치로 출발원료로는 직 경 3", 두께 1/4", 순도 $99.995 \%$ 의 TiAl 타겟을 사용하였 다. TiAIN 코팅막의 증착을 위해 초고순도 $99.999 \%$ 의 $\mathrm{N}_{2}$ 와 $\mathrm{Ar}$ 가스를 사용하였고 $\mathrm{Ar}$ 과 $\mathrm{N}_{2}$ 가스의 분압조절은 MFC (Mass Flow Controller)를 이용하여 조절하였다. 증착 시 기판과 타겟간 거리는 $60 \mathrm{~mm}$ 로 유지하고, 균일한 증 착을 위해 기판을 약 $10 \mathrm{rpm}$ 의 속도로 회전시켰다. TiAlN 코팅막은 $\mathrm{Ar}$ 과 $\mathrm{N}_{2}$ 를 적절히 혼합한 분위기에서 증착하였 다. 챔버의 초기압력은 로터리 펌프와 터보분자펌프를 사 용하여 약 $4.0 \times 10^{-4} \mathrm{~Pa}$ 까지 배기시켰으며 진공도의 측정 은 이온 게이지와 바라트론게이지를 이용하였다. 증착 전 에 타겟과 기판을 세척하기 위해 $\mathrm{Ar}$ 플라즈마를 발생시 켜 처리하였다. 코팅막의 물성 비교 및 분석을 위해 종래 의 $\mathrm{DC}$ 전원과 펄스 $\mathrm{DC}$ 전원을 이용하여 TiAlN 코팅막 을 제작하였으며 Table 1에 자세한 비대칭 펄스 플라즈마 성막 조건을 타내었다. 또한 얻어진 나노결정질 TiAIN 코 팅막의 결정구조, 우선 배향성 및 반가폭 등의 분석을 위 해 고분해능 XRD (PAN analytical사 / X'pert- pro MRD) 를 사용하였고, FE-SEM (Hitachi사 / S-3500N)을 이용하 여 코팅막의 표면과 단면의 미세구조를 관찰하였다. 3 차 원적 몰폴러지와 표면 거칠기 측정을 위해 Auto Probe Atomic Force Microscopy (AFM)(Digital Instruments사 / Nanoscope 3a)을 이용하였다. 코팅막의 나노경도 측정은

Table 1. Conditions for Deposition of TiAlN Coatings by Continuous DC and Pulsed DC Sputtering

\begin{tabular}{ccccc}
\hline Conditions & 1 & 2 & 3 & 4 \\
\hline Generator (type) & DC & Pulsed DC Pulsed DC Pulsed DC \\
Power (W) & 500 & 500 & 500 & 500 \\
Pulse frequency (kHz) & - & 5 & 25 & 50 \\
Duty cycle (\%) & - & 95 & 75 & 50 \\
Substrate bias voltage (V) & DC-100 & DC-100 & DC-100 & DC-100 \\
\hline
\end{tabular}

한국세라믹학회지
정밀경도시험기인 나노인덴터 (MTS System사 / MTS XP) 를 이용하였다. 경도는 Berkovich 다이아몬드 압자를 이 용하여 16 번의 실험을 통한 평균값으로 구하였다. 나노인 덴터 측정 간격은 이미 실행된 경도 측정 팁에 영향을 받 지 않기 위해 $10 \mu \mathrm{m}$ 이상을 유지하였다. 또한 모재에 영 향을 끼치지 않는 범위에서 경도를 측정하기 위해 압입 깊이는 코팅막의 두께의 $10 \%$ 정도로 고정하였다.

\section{3. 결과 및 고찰}

\section{1. 결정립 크기}

코팅막의 평균 결정립 크기는 거의 모든 분야의 응용 분야에서 물성을 좌우하는 매우 중요한 요소로 결정립 크 기의 감소는 잔류응력과 경도를 증가시켜 코팅막의 접착 력과 내마모성을 향상시킨다. 따라서 결정립 크기의 정확 한 측정은 코팅막의 응용 최적화에 매우 중요한 요소이 다. 결정립 크기 측정을 위해 투과전자 현미경을 이용하 면 일반적으로 시편제작과 관찰에 많은 시간과 비용이 요 구된다. 따라서 이를 개선하고 단순화시킨 새로운 접근방 법은 $\mathrm{X}$ 선 회절분석을 이용한 결정립 크기의 측정이다. ${ }^{11)}$ Fig. 1에 DC 스퍼터법 및 비대칭 바이폴라 펄스 $\mathrm{DC}$ 스 퍼터법으로 제작한 TiAlN 코팅막의 결정립 크기변화를 나타냈다. 코팅막의 결정립 크기는 X선 회절분석 피크의 반가폭 크기로도 계산이 가능한데 일반적으로 반가폭 크 기가 클수록 결정립 크기는 작아진다. 본 실험에서 결정 립 크기는 Scherrer법을 이용하여 계산하였고 반가폭이 증 가할수록 결정립 크기는 감소하였다. ${ }^{2)}$ 그림에서 알 수 있듯이 듀티 싸이클 감소와 펄스 주파수 증가에 따라 TiAlN 코팅막의 결정립 크기는 $68.5 \mathrm{~nm}$ 부터 $18.7 \mathrm{~nm}$ 까지 거의 직선적으로 감소함을 알 수 있다. 따라서 TiAlN 코 팅막의 미세구조를 제어하는 기술로서 비대칭 바이폴라 펄스 $\mathrm{DC}$ 스퍼터법과 듀티 싸이클 및 펄스 주파수는 매 우 중요한 공정변수임을 알 수 있다. ${ }^{13)}$

이러한 TiAlN 코팅막의 결정립 크기의 나노화 원인으 로는 이온 에너지, 이온 플럭스, 잔류 불순물 및 결정학

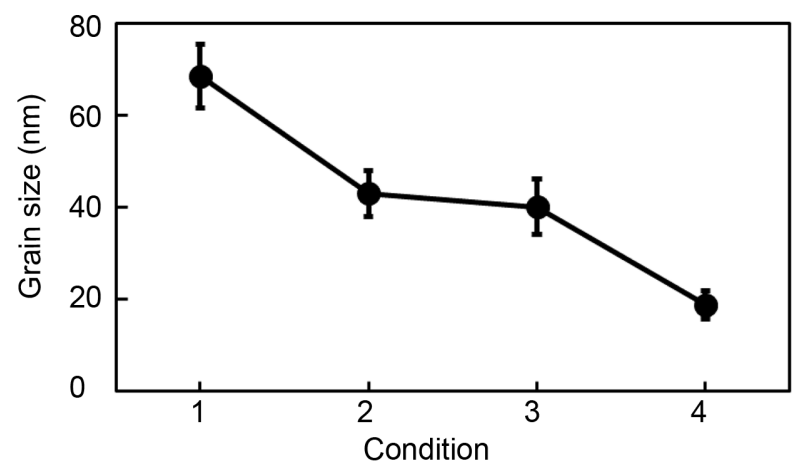

Fig. 1. The grain sizes of TiAlN films deposited by DC and pulsed DC sputtering. 


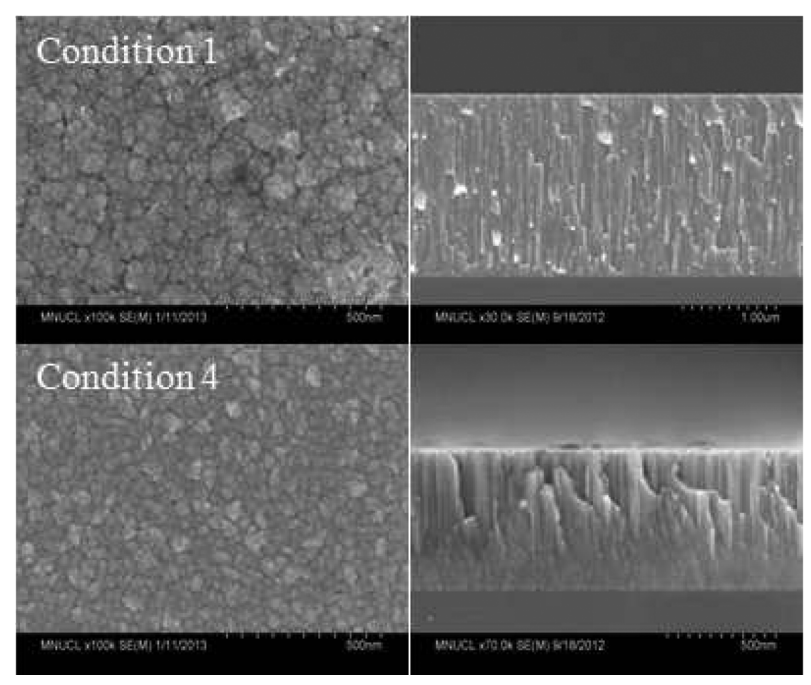

Fig. 2. Top surface and cross-sectional FE-SEM images of TiAlN films deposited by DC and pulsed DC sputtering.

적 집합조직과 같은 복합적인 요소들의 영향을 들 수 있 다. ${ }^{14)}$ 본 연구에서는 성막 중 음전하를 띤 스퍼터 원자의 포격이 코팅막 안에 손상을 입혀 다수의 결함이 막 안에 형성되었다고 사료된다. 이러한 결함의 밀도는 고에너지 의 스퍼터 원자 때문에 증가하게 되며 성막 중 기판 위 에 반복적인 핵생성을 유발시킨다. 불순물들은 입계에 석 출하게 되고 Zener drag로 인해 입성장이 제한되기 때문 에 이는 나노결정질 TiAIN 코팅막의 형성 및 유지에 매 우 유리하다. ${ }^{15}$

\section{2. 미세구조}

$\mathrm{DC}$ 및 펄스 $\mathrm{DC}$ 스퍼터법으로 제작된 TiAlN 코팅막의 미세구조를 FE-SEM을 이용하여 관찰하였고 그 표면 사 진을 Fig. 2에 나타내었다. DC 스퍼터로 제작된 TiAlN 코 팅막의 표면 사진에서는 평균크기 $60 \sim 80 \mathrm{~nm}$ 이상의 주 상구조의 다공성 결정립이, 펄스 $\mathrm{DC}$ 스퍼터로 제작된 TiAlN 코팅막의 표면에서는 평균크기 $10 \sim 20 \mathrm{~nm}$ 이하의 치밀한 결정립으로 미세화되어감을 관찰할 수 있다. 일반 적으로 펄스 플라즈마의 생성에 따른 이온전류의 상승은 핵생성 밀도를 증가시켜 결과적으로 매우 작은 결정립으 로 구성된 치밀한 미세구조의 코팅막이 형성된다. 또한 본 연구에서는 성막 중 기판에 $\mathrm{DC}-100 \mathrm{~V}$ 의 바이어스 전 압을 인가했기 때문에 $60 \sim 80 \mathrm{eV}$ 범위의 이온 에너지 분

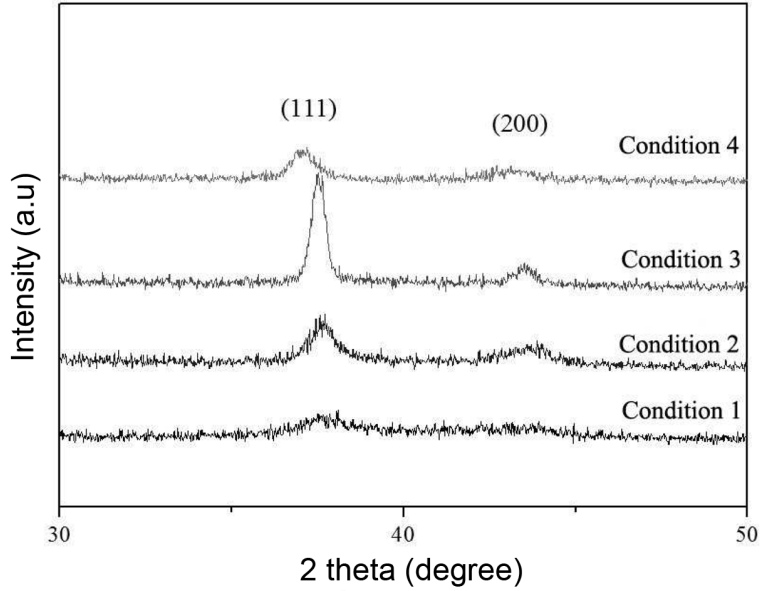

Fig. 3. XRD data of TiAlN films deposited using DC and pulsed DC sputtering.

포를 갖는 다수의 이온들이 기판을 향해 이온 포격된 것 으로 사료된다. ${ }^{16)}$ 따라서 이러한 이온 포격효과와 성막속 도의 감소 (condition 4 의 경우 약 $0.1 \mathrm{~nm} / \mathrm{s}$ 로 condition 1 에 비해 $1 / 3$ ) 라는 복합적인 요소에 의해 코팅막의 미세 구조는 미세화 및 치밀화되었다고 사료된다.

\section{3. 우선 배향성 및 잔류응력}

$\mathrm{DC}$ 스퍼터법 및 비대칭 바이폴라 펄스 스퍼터법으로 제작한 TiAlN 코팅막의 X선 회절분석 결과를 Fig. 3에 나 타내었다. 모든 코팅막에서 (111)면과 (200)면의 피크가 관 찰되었으며, 코팅막 제작방법 및 공정변수 차이로 인한 $\mathrm{X}$ 선 회절분석 결과는 눈에 띄는 변화가 우선 배향성에서 는 발견되지 않았다. 그러나 비대칭 바이폴라 펄스 스퍼 터법의 사용과 코팅 중 듀티 싸이클의 감소 및 펄스 주 파수 증가에 따라 $\mathrm{X}$ 선 회절분석 피크의 반가폭은 연속적 으로 감소함을 알 수 있다. 코팅 중 듀티 싸이클 및 펄스 주파수가 TiAIN 코팅막 내에 잔류응력에 미치는 영향을 알 아보기 위해 (111)면과 (200)면의 $2 \theta$ 분석결과를 Table 2에 나타내었다. 코팅 중 펄스 플라즈마 변수에 따라 TiAIN 회절 피크의 포지션 변화에 미치는 영향을 쉽게 표현하 기 위해 JCPDS 카드(\#37-1140)로부터 구한 TiAIN (111) 면과 (200)면의 표준 $2 \theta$ 값을 함께 표시했다. 펄스 플라즈 마 공정변수에 따라서 (111)면과 (200)면의 측정 2 2 값은 TiAlN JCPDS 카드의 표준 20값보다 감소함을 명확히 알 수 있다. 이러한 $2 \theta$ 값의 저각으로의 이동은 응력변화에

Table 2. XRD Data of TiAIN Films for DC and Pulsed DC Sputtering

\begin{tabular}{|c|c|c|c|c|c|c|c|c|c|c|}
\hline \multirow{2}{*}{ TiAIN } & \multicolumn{10}{|c|}{ Peak position } \\
\hline & \multicolumn{5}{|c|}{ (111) } & \multicolumn{5}{|c|}{$(200)$} \\
\hline Duty cycle $(\%)$ & 100 & 95 & 75 & 50 & standard & 100 & 95 & 75 & 50 & standard \\
\hline $2 \theta\left({ }^{0}\right)$ & 38.13 & 37.71 & 37.23 & 37.04 & 37.88 & 43.96 & 43.90 & 43.54 & 42.92 & 44.04 \\
\hline
\end{tabular}


기인한다고 사료된다.

일반적으로 PVD 프로세스를 이용하여 제작된 코팅막 에는 상당량의 잔류응력이 존재하기 때문에 내마모성과 경도가 증가하나 반면 접착력은 감소한다. ${ }^{17)}$ 이러한 $\mathrm{PVD}$ 프로세스를 이용하여 제작된 코팅막에 존재하는 압축응 력은 $\mathrm{Ar}^{+}$이온 포격에 의해 생성된 점 결함과 밀접한 관 계를 갖는다. 주상구조를 갖지 않는 치밀한 미세구조를 갖는 코팅막을 제작하기 위해서는 이온 포격이 요구되며 이러한 이온 포격효과는 결정립 크기의 미세화 및 부착 력 향상에 커다란 영향을 미친다. ${ }^{18)}$ 실제로 본 실험에서 얻어진 TiAlN 코팅막 내부에는 상당량의 잔류응력이 존 재한다고 사료된다. 그 증거로서 Table 2의 X선 회절분석 결과를 면밀히 관찰해보면 DC 스퍼터법으로 제작된 TiAIN 코팅막의 20 값보다 펄스 $\mathrm{DC}$ 스퍼터법으로 제작된 TiAIN 코팅막이 낮은 29 값을 갖고 있음을 알 수 있는데 이는 코 팅막내부 압축응력의 증가를 시사한다. ${ }^{19)}$

\section{4. 표면 거칠기}

코팅 중 듀티 싸이클과 펄스 주파수 변화가 TiAIN 코 팅막의 표면 거칠기에 미치는 영향을 밝히기 위해 비접 촉식 $\mathrm{AFM}$ 분석을 실시하였고 그 결과를 Fig. 4에 나타 내었다. 코팅 중 듀티 싸이클과 펄스 주파수가 TiAIN 코 팅막의 $\mathrm{R}_{\mathrm{a}}$ (Roughness average) 표면 거칠기에 미치는 결 과를 비교하면 펄스 스퍼터법으로 제작한 TiAIN 코팅막 의 표면이 종래의 DC 스퍼터법으로 코팅한 TiAIN 코팅막
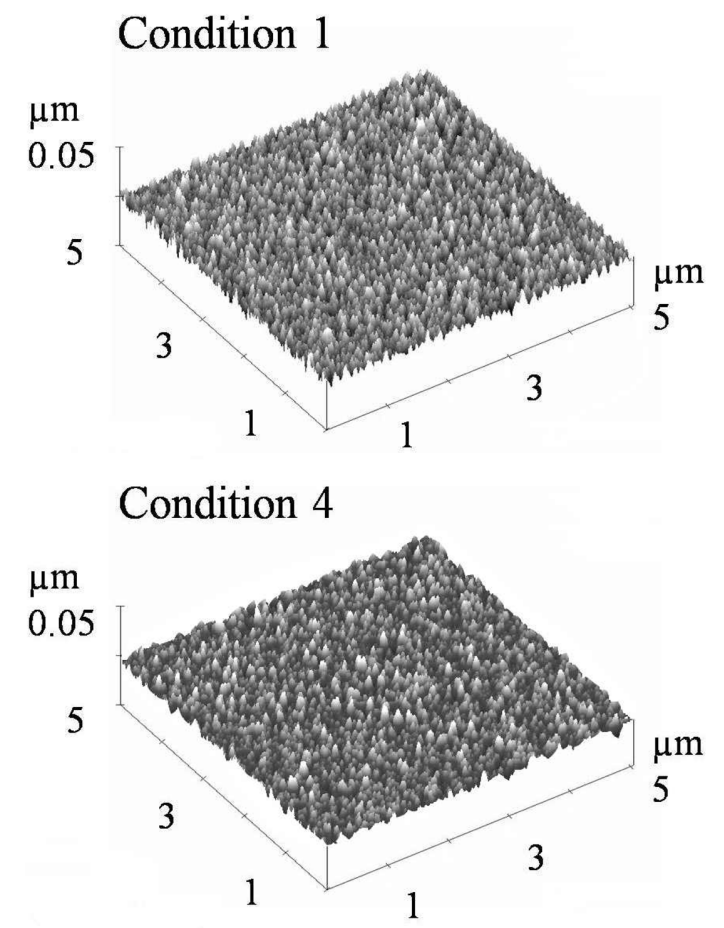

Fig. 4. AFM surface morphologies of TiAIN films deposited using DC and pulsed DC sputtering.
보다 평탄하다는 점이다. 예를 들면 연속적인 $\mathrm{DC}$ 스퍼터 법으로 제작한 TiAIN 코팅막의 $\mathrm{R}_{\mathrm{a}}$ 표면 거칠기는 $3.1 \mathrm{~nm}$ 인 반면 듀티 싸이클 $50 \%$ 와 펄스 주파수 $50 \mathrm{kHz}$ 를 인가하 여 제작한 TiAlN 코팅막의 $\mathrm{R}_{\mathrm{a}}$ 표면 거칠기는 $2.4 \mathrm{~nm}$ 이다. 펄스 스퍼터법으로 제작된 TiAIN 코팅막의 매끄러운 표 면 몰폴러지는 이온 전류 밀도와 밀접한 관계를 갖는다 고 보고된바 있으며, 실제로 펄스 $\mathrm{DC}$ 스퍼터법을 이용하 면 $\mathrm{DC}$ 스퍼터법에 비해 약 $40 \sim 80 \%$ 높은 이온 전류가 얻어진다고 보고되고 있다. ${ }^{20)}$ 따라서 본 연구에서도 위와 같은 펄스 플라즈마의 생성에 따른 이온전류의 증가가 매 끄러운 표면 몰폴러지를 갖는 TiAlN 코팅막의 형성에 기 여했다고 사료된다.

\section{5. 나노 경도}

$\mathrm{DC}$ 스퍼터법 및 비대칭 펄스 스퍼터법으로 제작한 TiAlN 코팅막의 기계적 경도를 나노인덴테이션 장비를 이 용하여 측정하였고 이를 Fig. 5에 나타내었다. 나노인덴테 이션 기술은 아주 작은 양의 재료의 기계적 성질을 얻기 위해 가장 간단하고 직접적인 방법으로 사용된다. ${ }^{21)}$ 본 연 구에서 코팅막의 나노 경도 측정을 위한 입자의 인가하 중은 $5 \mathrm{mN}$ 으로 고정했으며, 압입 깊이가 얕을수록 측정 된 경도 값이 증가하는 경향을 보이는 인덴테이션 크기 효과 ${ }^{22)}$ 를 배제하기 위하여 전체 막 두께의 $1 / 10$ 지점으 로 평균화하였다. 본 연구 결과에서 종래의 $\mathrm{DC}$ 스퍼터법 보다 비대칭 펄스 $\mathrm{DC}$ 스퍼터법으로 제작한 TiAlN 코팅 막의 나노 경도값이 높음을 알 수 있다. 이러한 TiAlN 코 팅막의 나노 경도는 듀티 싸이클의 감소와 펄스 주파수 의 증가에 따라 증가함을 알 수 있는데 예를 들면 듀티 싸이클 $50 \%$ 와 펄스 주파수 $50 \mathrm{kHz}$ 에서 제작된 TiAlN 코 팅막의 나노 경도값은 약 $22 \mathrm{GPa}$ 로 $\mathrm{DC}$ 스퍼터법으로 제 작한 TiAlN 코팅막의 나노 경도값 $15 \mathrm{GPa}$ 보다 약 1.5 배 증가함을 알 수 있다. 이러한 펄스 $\mathrm{DC}$ 스퍼터법으로 제 작된 TiAlN 코팅막의 나노 경도의 상승원인은 $\mathrm{DC}$ 스퍼 터법으로 제작한 TiAIN 코팅막에 비해 높은 이온화를 가 지며 고밀도 플라즈마의 생성으로 인한 결정립 크기의 감

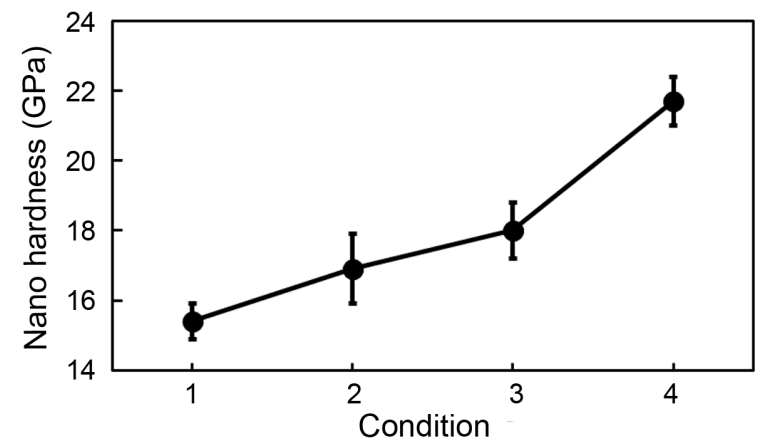

Fig. 5. The nanoindentation hardness of TiAIN films prepared at DC and pulsed DC sputtering. 
소에 따른 미세구조의 치밀화, 기판바이어스 전압인가에 따른 높은 이온포격효과 및 압축응력의 상승에 주로 기 인한다고 사료된다.

\section{4. 결 론}

본 연구에서는 타겟에 인가되는 펄스 플라즈마 전원의 사용과 듀티 싸이클과 펄스 주파수와 같은 펄스 플라즈 마 공정변수가 TiAIN 코팅막의 나노 결정립 크기와 몰폴 러지와 같은 미세구조적 변화와 우선 배향성과 나노 경 도와 같은 기계물리학적 특성 변화에 미치는 영향에 대 해 조사하기 위하여 비대칭 바이폴라 펄스 $\mathrm{DC}$ 스퍼터법 을 이용하여 나노결정질 TiAlN 코팅막을 제작하였다. 듀 티 싸이클 $50 \%$ 와 펄스 주파수 $50 \mathrm{kHz}$ 를 인가하여 제작 된 TiAlN 코팅막의 평균 결정립 크기와 $\mathrm{R}_{\mathrm{a}}$ 표면 거칠기 는 각각 $18.7 \mathrm{~nm}$ 와 $2.4 \mathrm{~nm}$ 로 가장 조밀하고 평탄한 몰폴 러지를 갖는 코팅막을 제작할 수 있었다. X선 회절분석 결과 주로 (111)면의 집합조직발달이 관찰되었으나 (111) 면과 (200)면 모두 29값은 감소하여 TiAlN 코팅막 내 압 축응력이 증가함을 나타냈다. 또한 비대칭 바이폴라 펄스 스퍼터법으로 제작한 TiAlN 코팅막의 나노 경도는 약 22 $\mathrm{GPa}$ 로 $\mathrm{DC}$ 스퍼터법으로 제작한 코팅막에 비해 약 1.5 배 증가하였다.

\section{Acknowledgment}

본 과제(결과물)는 교육부의 재원으로 지원을 받아 수 행된 산학협력 선도대학(LINC) 육성사업의 연구결과입니다.

\section{REFERENCES}

1. S. J. Lee, "Wear Behavior of Alumina-glass Composites Prepared by Melt Infiltration(in Korean)," J. Kor. Ceram. Soc., 40 [9] 881-85 (2003).

2. T. S. Kwank, "Properties of Mirror-surface Grinding for Metal Matrix Ceramic Composites(in Korean)," J. Kor. Ceram. Soc., 49 [1] 90-94 (2012).

3. M. J. Chaichi and S. O. Alijanpour, "Chitosan-induced Au/ Ag Nanoalloy Dispersed in IL and Application in Fabricating an Ultrasensitive Glucose Biosensor Based on luminol- $\mathrm{H}_{2} \mathrm{O}_{2}-\mathrm{Cu}^{2+} / \mathrm{IL}$ Chemiluminescence System," Surf. Coat. Technol., 40 41-48 (2014).

4. K. M. Nam, Y. J. Lee, O. Y. Kim, W. T. Kwon, and S. R. Kim, "Biomimetic Preparation of Boron Nitride /PMMA Composite(in Korean), " J. Kor. Ceram. Soc., 51 [2] 103-06 (2014).

5. J. H. Shim, S. W. Cha, T. M. Gür, and F. B. Prinz, "Fuel Cells for Intermediate Temperature Operations(in Korean)," J. Kor. Ceram. Soc., 43 [12] 751-57 (2006).

6. S. Y. Yoon, J. K. Kim, and K. H. Kim, "A Comparative Study on Tribological Behavior of TiN and TiAlN Coatings
Prepared by arc Ion Plating Technique," Surf. Coat. Technol., 161 [2-3] 237-42 (2002).

7. D. H. Seo and S. Y. Chun, "A Comparative Study of $\mathrm{CrN}$ Coatings Deposited by DC and Inductively Coupled Plasma Magnetron Sputtering," J. Kor. Ceram. Soc., 45 [3] 123-29 (2012).

8. K. S. Nam, J. I. Moon, P. Kongsy, J. H. Song, and D. Y. Lim, "Influence of the Duty Cycle on the Characteristics of $\mathrm{Al}_{2} \mathrm{O}_{3}$ Coatings Formed on the Al-1050 by Plasma Electrolytic Oxidation(in Korean)," J. Kor. Ceram. Soc., 50 [2] 108-15 (2013).

9. B. Y. Kim, J. G. Kim, D. Y Lee, M. Jeon, Y. N. Kim, S. Y. Kim, and K. Y. Kim, "Effect of $\mathrm{Na}_{2} \mathrm{P}_{2} \mathrm{O}_{7}$ Electrolyte and $\mathrm{Al}$ Alloy Composition on Physical and Crystallographical Properties of PEO Coating Layer : I. Physical Properties of PEO Layer(in Korean)," J. Kor. Ceram. Soc., 49 [3] 241-46 (2012).

10. J. S. Lee, C. S. Ki, and S. K. Joo, "A Study on the Saturation of Grain Size in $\mathrm{Pb}(\mathrm{Zr}, \mathrm{Ti}) \mathrm{O}_{3}$ Thin Films $($ in Korean)," J. Kor. Ceram. Soc., 49 [6] 498-504 (2012).

11. D. Cullity and S. R. Stock, Element of X-ray Diffraction; pp. 167, Prentice-Hall Inc., 3rd, 2001.

12. S. M. Ko, S. M. Koo, J. H. Kim, W. S. Cho, and K. T. Hwang "Synthesis of Silicon Carbide Nano-powder from a Silicon-organic Precursor by RF Inductive Thermal Plasma (in Korean)," J. Kor. Ceram. Soc., 49 [6] 523-27 (2012).

13. H. C. Barshilia and K. S. Rajam, "Reactive Sputtering of Hard Nitride Coatings Using Asymmetric-bipolar Pulsed DC Generator," Surf. Coat. Technol., 201 [3-4] 1827-35 (2006).

14. M. G. Han and S. Y. Chun, "Growing Behavior of Nanocrystalline TiN Films by Asymmetric Pulsed DC Reactive Magnetron Sputtering(in Korean)," J. Kor. Ceram. Soc., 48 [5] 342-47 (2011).

15. D. H. Seo and S. Y. Chun, "Growth Behavior of Nanocrystalline CrN Coatings by Inductively Coupled Plasma (ICP) Assisted Magnetron Sputtering(in Korean)," J. Kor. Ceram. Soc., 49 [6] 556-60 (2012).

16. S. W. Park and S. Y. Chun "A Comparative Study of CrN Coatings Deposited by DC and Pulsed DC Asymmetric Bipolar Sputtering for a Polymer Electrolyte Membrane Fuel Cell (PEMFC) Metallic Bipolar Plate(in Korean)," $J$. Kor. Ceram. Soc., 50 [6] 390-95 (2013).

17. H. M. Choi and S. K. Choi, "Residual Stress and Growth Orientation in $\mathrm{Y}_{2} \mathrm{O}_{3}$ Thin Films Deposited by Reactive Sputtering," J. Kor. Ceram. Soc., 32 [8] 950-56 (1995).

18. S. N. Chvalun, J. Blackwell, J. D. Cho, Y. K. Kwon, V. Percec, and J. A. Heck "X-ray Analysis of the Internal Rearrangement of the Self-assembling Columnar Structure Formed by a Highly Tapered Molecule," Surf. Coat. Technol., 39 [19] 4515-22 (1998).

19. S. Y. Chun, "Microstructure and Mechanical Properties of Nanocrystalline TiN Films Through Increasing Substrate Bias(in Korean)," J. Kor. Ceram. Soc., 47 [6] 479-84 (2010)

20. J. Lina, I. Dahan, B. Valderrama, and M. V. Manuel, "Structure and Properties of Uranium Oxide Thin Films Deposited by Pulsed DC Magnetron Sputtering," Surf. Coat. Technol., 
301 475-80 (2014).

21. H. S. Park, D. H. Jung, H. D. Na, J. H. Joo, and J. J. Lee, "The Properties of (Ti,Al)N Coatings Deposited by Inductively Coupled Plasma Assisted D.C Magnetron Sputtering," Surf. Coat. Technol., 142-144 [7] 999-1004 (2001).
22. Z. Song and K. Komvopoulos, "An Elastic-plastic Analysis of Spherical Indentation: Constitutive Equations for Singleindentation Unloading and Development of Plasticity due to Repeated Indentation," Surf. Coat. Technol., 76 93-101 (2014). 